\title{
Dendrogeomorphically derived slope response to decadal and centennial scale climate variability: Black Mesa, Arizona, USA
}

\author{
L. A. Scuderi ${ }^{1,2}$, L. D. McFadden ${ }^{1}$, and J. R. McAuliffe ${ }^{3}$ \\ ${ }^{1}$ Dept. of Earth and Planetary Sciences, Northrop Hall, MSC 03-2040, Univ. of New Mexico, Albuquerque, NM, USA \\ ${ }^{2}$ Center for Rapid Environmental Assessment and Terrain Evaluation, Univ. of New Mexico, Albuquerque, NM, USA \\ ${ }^{3}$ Desert Botanical Garden, 1201 N. Galvin Parkway, Phoenix, AZ, USA
}

Received: 20 November 2007 - Revised: 20 May 2008 - Accepted: 18 July 2008 - Published: 18 August 2008

\begin{abstract}
A major impediment to an understanding of the links between climate and landscape change, has been the relatively coarse resolution of landscape response measures (rates of weathering, sediment production, erosion and transport) relative to the higher resolution of the climatic signal (precipitation and temperature on hourly to annual time scales). A combination of high temporal and spatial resolution dendroclimatic and dendrogeomorphic approaches were used to study relationships between climatic variability and hillslope and valley floor dynamics in a small drainage basin in the Colorado Plateau of northeastern Arizona, USA Dendrogeomorphic and vegetation evidence from slopes and valley bottoms, including root exposure, bending of trunks, change in plant cover and burial and exhumation of valley bottom trees and shrubs, suggest that the currently observed process of root colonization and rapid breakdown of the weakly cemented bedrock by subaerial weathering, related to periodic dry/wet cycle induced changes in vegetation cover, has lead to a discontinuous, climate-controlled production of sediment from these slopes. High-amplitude precipitation shifts over the last 2000-years may exert the largest control on landscape processes and may be as, or more, important than other hypothesized causal mechanisms (e.g. ENSO frequency and intensity, flood frequency) in eroding slopes and producing sediments that ultimately impact higher order drainages in the region. Current vegetation response to a prolonged drought over the past decade suggests that another major transition, incorporating vegetation change, slope erosion, sediment production and subsequent valley floor deposition, may be in its initial phase.
\end{abstract}

\section{Correspondence to: L. A. Scuderi} (tree@unm.edu)

\section{Introduction}

An important goal in global change studies is development of an understanding of how landscapes have responded to past climate variability and, in light of recent trends, how they might respond to potential future changes in the magnitude and frequency of precipitation events. Key to this response is the linked climate-vegetation system that influences the amount of moisture available for eroding slopes. On short timescales, ranging from a year to several years, this system is a sensitive balance between incident precipitation supplied by the climate system, soil properties that control infiltration and surface runoff, and surface vegetation cover which modulates surface runoff through interception of precipitation and evapotranspiration.

On longer timescales, linked climate and vegetation changes are likely to have a significant impact on erosion and sediment production on sparsely vegetated slopes, through change in precipitation intensity, duration and surface exposure. Ultimately these changes will impact the delivery of sediments to basins downslope. In the Western United States, Hereford (2002) documented a period of channel aggradation on the Colorado Plateau between AD 1400 and AD 1860, which he attributed to a reduction in the long-term decrease in the frequency of large floods during the colder Little Ice Age. Climate change of this magnitude is likely to produce significant fluctuations in slope processes and sediment transport and can also impact water supply, reservoir lifetimes (through filling) and water quality.

Understanding how current variability in climate and vegetation in the Southwestern United States impacts erosion on slopes and subsequent sediment yield is important because modeling studies (Zhang et al., 2007; Seager et al., 2007) suggest that semi-arid regions globally may experience considerable change in their precipitation regimes in response

Published by Copernicus Publications on behalf of the European Geosciences Union. 
to current and future climate warming. Seager et al. (2007) note that a drying trend has begun in the Southwestern North America (SWNA) and these drier conditions may persist and become the climatic normal for the region. Current conditions may be moving towards a persistent hot-dry climatic regime where current vegetation patterns may be altered over extensive areas within a short time frame (Allen and Breshears, 1998; Floyd et al., 2004; Gray et al., 2006; Breshears, et al., 2005; Seager et al., 2007). Establishment of persistent hot-dry regimes could disrupt woody vegetation that germinated during preceding wet-cool periods (Gray et al., 2006) and potentially increase erosion from sensitive slopes. Studies also suggest that the climate change associated with this variability may be unprecedented in the historic record and may result from mechanisms that are different from those that were operational over the past several thousand years (Seager et al., 2007).

Exposed roots have been used in many studies to calculate denudation rates and gully erosion (see Gartner, 2007 for a recent review). However, the utility of this evidence from individual slopes in understanding how these surfaces respond to climate change is often lacking since dendrogeomorphic evidence is rarely linked to the larger regional climate pattern or to long-term variability in climate indices. When dendrogeomorphic evidence is placed in the context of regional climate and vegetation change a fuller understanding the mechanisms that control production and movement of sediment from these slopes is possible.

In this study we offer a four-part approach to addressing the problem of erosion and deposition in the Black Mesa area of the American Southwest. We date the timing of regional shifts in tree growth using dendrochronology, relate these changes to regional climate variability over the past two millennia using dendroclimatology, link the slope and basin response to these climatic inputs using dendrogeomorphology and finally associate the overall pattern of droughtinduced changes in vegetation density with recent changes in vegetation cover due to extreme mortality (Breshears et al., 2005; Yuhas and Scuderi, Geogr. Res., in press, 2009).

\section{Scientific background}

The recent erosional and depositional history of the Southwestern United States has generated a wealth of literature over the past 100 years. Rich (1911), Bryan (1925) and Swift (1926) were among the first to summarize the evidence for significant variability in erosion and deposition and resultant landform change, especially the production of arroyos in valley bottoms. Early attempts were made to link this change to climate variability by Huntington (1914) who noted that a slight drying of climate would decrease vegetative cover, increase runoff and alter the erosional and depositional dynamics of individual drainages. Alternatives to a climate induced valley-bottom/channel change model included both impacts of grazing and human activity during the settlement period in the mid-to-late 1800s (Hough, 1906) and random variations unrelated to climate or human activity (see Cooke and Reeves, 1976; Schumm, 1977, 1991; Patton and Schumm, 1981; Waters and Haynes, 2001; Hereford, 2002; for a discussion of the multiple hypotheses, evidence and conflicting arguments regarding the causality of these landscape changes in the American Southwest). We note here that evaluation of most of these hypotheses has been limited by the lack of key data (e.g. seasonal and annual scale precipitation records and detailed reconstructions of slope movement and deposition in adjacent basins) and uncertainty as to the timing of events.

\subsection{Study area}

Study sites at which we evaluated slope erosion and dendrogeomorphic response to climatic inputs are located at elevations between 1800 and 2200 meters on the Navajo Indian Reservation approximately $30 \mathrm{~km}$ west of Chinle, Arizona (McAuliffe et al., 2006; Fig. 1). This area, at the eastern edge of Black Mesa, is characterized by first to fourth-order drainages eroded into the relatively weak sandstones, siltstones and mudstones of the Jurassic Morrison Formation and underlying Bluff Sandstone (San Rafael Group) (Tillery et al., 2003). Within the study area average drainage basin length is approximately $1.5 \mathrm{~km}$ with most basins trending east-west. Slopes studied in the first and second-order tributary drainages typically are 40 to $60 \mathrm{~m}$ in length and 100 to $200 \mathrm{~m}$ in width and range from shallow slopes to nearvertical cliff faces with local relief ranging from 30 to $80 \mathrm{~m}$. Valley bottoms in the upper portions of these drainages are typically 200 to $400 \mathrm{~m}$ wide.

Headward cutting of non-vegetated cliff faces, erosion from lateral slopes, and erosion from reworking of valley bottom deposits provide inputs into the main trunk, 4th order Cottonwood Wash drainage, $\approx 2.5 \mathrm{~km}$ from the drainage divide. Significant aspect related topoclimatic variability impacts both vegetation (e.g. type and density) and slope form (Burnett, 2004; Burnett et al., 2008). The study area slopes are too rugged to be grazed by livestock and we find no evidence for past livestock use on these slopes.

Tree ring data used in the dendroclimatic analysis reported in this paper were selected from over 250 tree ring chronologies that cover portions of Utah, Colorado, Arizona and New Mexico (Contributors to the International Tree Ring Data Base, 2007). Cook et al. (1999, appendix B) have shown that the calibration $R^{2}$ values (RSQ), verification $R^{2}(\mathrm{RR})$, Reduction of Error statistic (RE) and the Coefficient of Efficiency (CE) of climatic reconstructions show a ridge of maximum reconstruction fidelity that consistently falls in a range from 400 to $500 \mathrm{~km}$ from grid point locations and concluded that a search radius of $450 \mathrm{~km}$ was the best search radius to use for reconstruction of climate over large areas. We use tree-ring datasets within $400 \mathrm{~km}$ of a centroid focused in the Four Corners (Fig. 2) to evaluate the regional climate signal. 


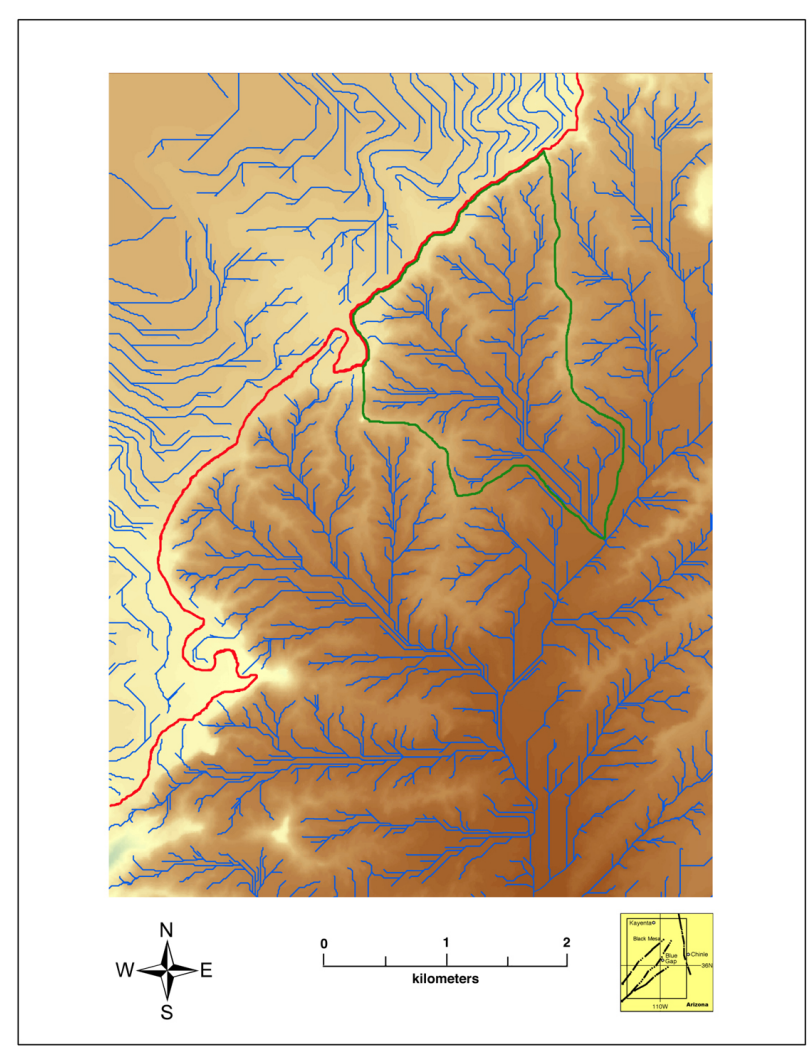

Fig. 1. Northeastern Arizona dendrogeomorphic study area. The fourth-order northeast to southwest trending drainages include Cottonwood Wash, which drains the study area. Study area with detailed dendrogeomorphic slope reconstructions, LiDAR mapping and cosmogenic dating outlined in green. Higher elevations are shown with lighter yellow tones. Red line indicates local drainage divide between local 4th-order drainages.

\section{Methods}

\subsection{Dendrogeomorphology}

Exposed roots have often been used to estimate the extent of surface erosion over timescales of hundreds to thousands of years (LaMarche, 1968; Alestalo, 1971; Dunne et al., 1978; Carrara, and Carroll, 1979; Danzer, 1996; Vandekerckhove et al., 2001; McAulliffe et al., 2006). In the study area visual evidence of slope erosion characterized by a combination of exposed roots, and curved trunks (Fig. 3) suggested that erosion rates were high and that dendrogeomorphic approaches could be used to date the timing and magnitude of erosional processes.

Pinyon pine (pinus edulis) trees on north-facing hillslopes were sampled to derive information on the vertical extent of soil erosion over the lifetimes of individual trees. For each of the 29 trees on the slope, diameter directly above the root crown, and slope inclination were recorded. Raw GPS co-

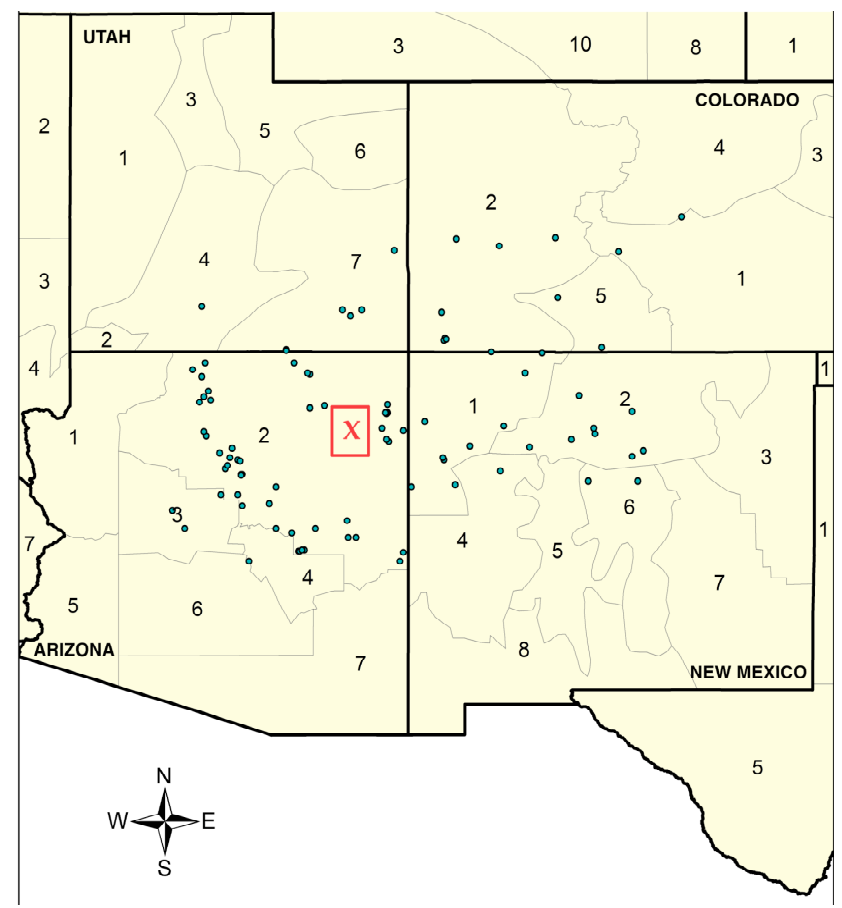

Fig. 2. Dendroclimatic study area. Dots indicate location of tree ring chronologies used in the analysis. The dendrogeomorphic study area is indicated by an $\mathrm{X}$ and is located in Arizona Climate Division 2 (NOAA), which covers the northeast portion of Arizona. Numbers indicate NOAA Climate Divisions for each state.

ordinates were collected for each tree on using a 12-channel TRIMBLE Pro XRS unit. GPS data was post-processed with base station data from Flagstaff, Arizona and Albuquerque, New Mexico and were used to produce a final slope map with horizontal and vertical positional accuracies of $\sim 40 \mathrm{~cm}$ and $\sim 80 \mathrm{~cm}$ respectively. Vegetation cover information and change over the eight-year period of our study was recorded across the study site using standard methods (McAuliffe, 1991).

Up to five increment cores were extracted with a minimum of two cores per tree, with one oriented transverse to the slope (generally east-west) and a second along the line of maximum slope (generally north-south). Of this collection, sets of cores from 20 trees were suitable for dendrogeomorphic reconstructions, five sets of cores were unusable due to extremely resinous sections that made precise dating impossible, and four trees yielded only broken and rotted cores. All cores were measured under microscope magnification, and skeleton-plotted using standard dendrochronological methods (Wigley et al., 1987).

Crossdating with a mean regional pinyon pine chronology derived from 59 precipitation-sensitive pinyon chronologies (Contributors of the International Tree-ring Data Bank, 2007) within a $300-\mathrm{km}$ radius of the study area in northeastern Arizona (as well as from an independent local 

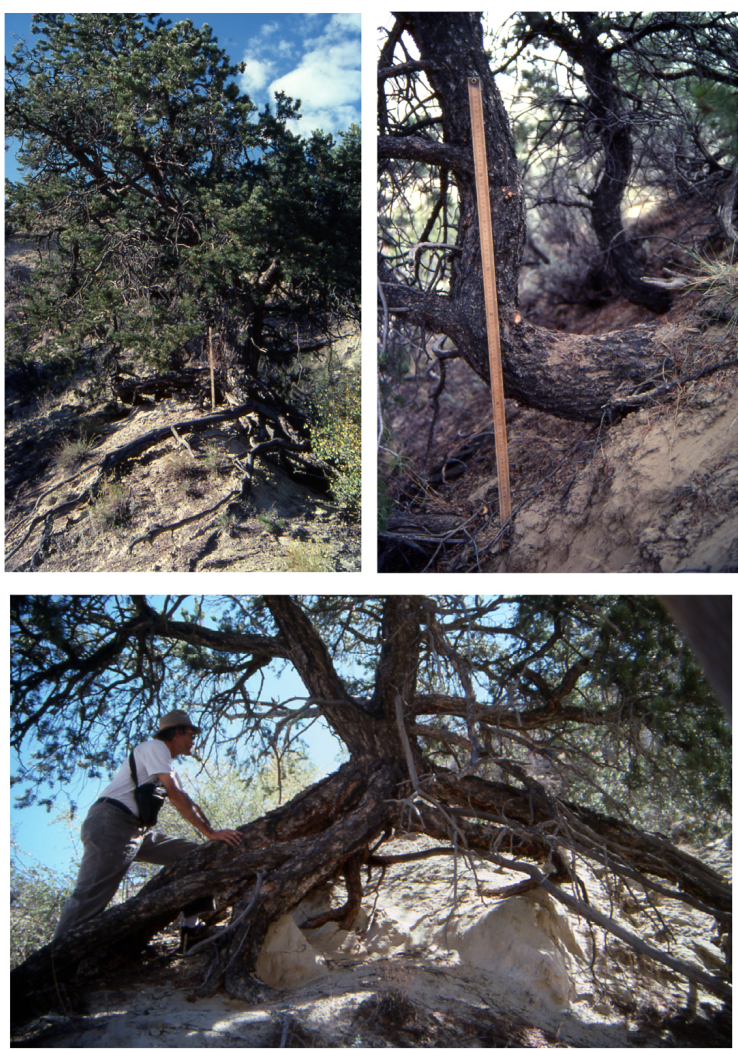

Fig. 3. Evidence of erosion and surface creep. Upper left: Exposed roots of 400 year old pinyon. Upper right: Slope creep. Lower: Exposed roots on ridgeline.

chronology derived from nearby trees on stable flat lying surfaces) were used for complete identification and assignment of zero-growth years (McAuliffe et al., 2006). Ringwidth measurements were standardized using a conservative linear detrending approach (Fritts 1976, Wigley et al. 1987) and then combined to produce a chronology for each tree and a site chronology for all trees on the eroding slope. A chronology of significant growth departures for each tree was calculated as the deviation from the mean regional pinyon chronology. Another set of approximately 20 slabbed cross-sections was collected from Utah juniper (Juniperus osteosperma) that is dominant on drier south-facing slopes. The majority of these trees were entirely dead with erosion exposing a significant portion of their root systems. Most of these trees were in their original growth position and showed no evidence of transportation from slopes to the valley floors. Because of serious problems with cross-dating due to missing rings, ring pinch-outs, and poorly defined ring boundaries commonly associated with juniper, estimates of their germination and death dates are less accurate than those of the pinyon pine.

\subsubsection{Population dynamics}

A goal of dendrochronology is to sample the population of a site using methods that capture the longest and most climatically sensitive record possible (Fritts, 1976). This process includes sampling the oldest specimens and coring all trees such that cores are oriented to intersect the pith. To evaluate age of germination an offset is applied to the innermost ring date to reflect the average age of a tree at the sampling height. When completed for many sites across a region cores collected can provide a statistically valid sampling of age structure with a bias towards older trees.

Gray et al. (2006) noted that pinyon pine recruitment is episodic and linked to strong decadal wet and dry regimes. Mortality during catastrophic droughts opens portions of the canopy allowing young seedlings to quickly colonize existing microtopographic niches. Most of this recruitment takes place during the first wet pulse following a prolonged drought. For this reason we hypothesized that it was likely that there would be gaps in the age structure of pinyons possibly related to extreme dry/wet cycles. To determine whether this die off occurred in our larger study area we analyzed archived tree ring records from 59 pinyon sites in the Western US and from those sites extracted pith dates for over 1400 individual trees (Contributors to the International Tree Ring Database, 2007) and developed an age structure curve for pinyon pine in the region.

\subsection{Dendroclimatology}

Over 250 tree ring chronologies from a region centered on the Four Corners states of the southwestern United States (Fig. 2) and archived in the International Tree Ring Data Base were examined for chronology depth, length and specifically for sensitivity to annual precipitation variation (Fritts, 1976; Hughes and Funkhouser, 1998). Correlations between specific climatic variables ( 26 precipitation and 26 temperature variables over a range of time scales) and growth were used screen the $\sim 250$ individual chronologies. Following standard procedures (Fritts, 1976; Cook et al., 1990; Briffa et al., 1992) we determined the optimal season for climate reconstruction for each of the 250 candidate sites. Each chronology was first correlated with local study site (NOAA Arizona Climate Division 2) temperature and precipitation data (NCDC, 1994) from AD 1895 to 1989 on monthly (prior June to September of the growth season), seasonal (prior Summer, prior Fall, prior Winter, prior Spring Summer) and annual time scales: 12-month (prior September to August) and 16-month windows (prior June to September; Table 1).

An additional correlation analysis for each chronology was performed with data from each of the Climate Divisions in Arizona, Utah, Colorado and New Mexico (see Fig. 2 for locations of each climate region) in order to assess whether there were significant climate responses both locally (within the surrounding climate division at each site) and regionally 
Table 1. Climatic variable correlation with growth. The number of chronologies with significant responses is indicated for each variable. Note that there were no significant negative precipitation responses or significant positive temperature responses.

\begin{tabular}{|c|c|c|c|}
\hline $\begin{array}{l}\text { Precipitation Variable } \\
\text { (Sums) }\end{array}$ & $\begin{array}{c}\text { Number of Significant } \\
\text { Positive Responses }\end{array}$ & $\begin{array}{l}\text { Temperature Variable } \\
\text { (Means) }\end{array}$ & $\begin{array}{l}\text { Number of Significant } \\
\text { Negative Responses }\end{array}$ \\
\hline Prior June & 0 & Prior June & 1 \\
\hline Prior July & 0 & Prior July & 70 \\
\hline Prior August & 0 & Prior August & 54 \\
\hline Prior September & 0 & Prior September & 0 \\
\hline Prior October & 0 & Prior October & 16 \\
\hline Prior November & 0 & Prior November & 5 \\
\hline Prior December & 12 & Prior December & 0 \\
\hline January & 6 & January & 0 \\
\hline February & 3 & February & 1 \\
\hline March & 0 & March & 0 \\
\hline April & 1 & April & 17 \\
\hline May & 0 & May & 24 \\
\hline June & 0 & June & 29 \\
\hline July & 32 & July & 45 \\
\hline August & 1 & August & 20 \\
\hline September & 0 & September & 0 \\
\hline Prior June to September & 77 & Prior June to September & 61 \\
\hline Prior Summer & 0 & Prior Summer & 55 \\
\hline Prior Fall & 0 & Prior Fall & 30 \\
\hline Prior Winter & 37 & Prior Winter & 0 \\
\hline Prior Spring & 1 & Prior Spring & 44 \\
\hline Summer & 6 & Summer & 52 \\
\hline Prior Fall to Winter & 18 & Prior Fall to Winter & 3 \\
\hline Prior Fall to Spring & 38 & Prior Fall to Spring & 34 \\
\hline Prior Fall to Summer & 84 & Prior Fall to Summer & 48 \\
\hline Prior Spring to Summer & 28 & Prior Spring to Summer & 74 \\
\hline
\end{tabular}

(to assess the degree of correlation across the larger study area). Sites that showed a strong correlation with summer precipitation, that correlated significantly with only a single monthly climate variable, or that were significantly correlated with temperature alone were eliminated from further consideration. We note that the area included in Fig. 2 is smaller than the area that Cook et al. (2004) used for their grid cell reconstructions of summer PDSI, and our screening process excluded chronologies that are to the south and southeast that have a strong monsoonal summer precipitation signal.

A subset of 111 tree ring chronologies with significant growth response to annual precipitation in Arizona Climate Division 2 (northeast Arizona) and with a chronology length greater than 200 years were selected for incorporation into a regionally based annual (prior September to August) precipitation sensitive chronology. Six annual precipitation sensitive chronologies from archaeological material (Dean and Robinson, 1978) were utilized to provide additional depth in the earlier centuries. Species included in the 117-chronology subset are Pinus edulis (pinyon pine), Pinus ponderosa (ponderosa pine), Pseudotsuga menziesii (Douglas fir), and Juniperus osteosperma (Utah juniper) and are represented in the composite chronology by 45, 37, 34 and 1 chronologies respectively.

Mean chronology length for the 117 chronologies is 482 years and ranges from a maximum of 1912 years to a minimum of 205 years. Minimum chronology depth is three between AD 1 and AD 400, seven between AD 400 and 1250, and then increases rapidly to 46 by AD 1500 and 110 by AD 1650. The mean interseries correlation during the climate calibration interval of 1895 to 1989 is 0.576 , with 73 percent of the chronologies correlated at greater than 0.50 even though they represent different species and occur at different locations across their species range. Of the 117 chronologies retained for further analysis 84 were most significantly correlated with prior fall to late-summer precipitation and 77 were also significantly correlated to a longer 16-month window that also includes prior summer season precipitation (prior June to September of the growth season; Table 1).

Because of the general similarity in the precipitation response for all 117 chronologies, they were combined to produce a master regional chronology with greatly enhanced chronology depth. While such an approach is not designed to preserve low-frequency variance beyond a few hundred years (Cook, et al., 1995) it is appropriate for resolution of 
Table 2. Ranked wet and dry intervals between AD 200 and 1989. The differences between precipitation estimates for year $\mathrm{X}$ and year $\mathrm{X}-50$ are represented by the 50 -year trend.

\begin{tabular}{ccccccccc}
\hline & \multicolumn{2}{c}{ 10-YR PERIOD } & \multicolumn{2}{c}{ 20-YR PERIOD } & \multicolumn{2}{c}{ 50-YR PERIOD } & \multicolumn{2}{c}{ 50-YR TREND } \\
Rank & DRY & WET & DRY & WET & DRY & WET & NEG. & POS. \\
\hline 1 & 707 & 1915 & 1582 & 1914 & 1155 & 1929 & 1954 & 1906 \\
2 & 516 & 1113 & 1285 & 1203 & 1458 & 486 & 1652 & 1192 \\
3 & 1582 & 729 & 708 & 579 & 1582 & 333 & 1275 & 491 \\
4 & 564 & 500 & 610 & 1119 & 1275 & 789 & 1149 & 1325 \\
5 & 365 & 1061 & 252 & 275 & 381 & 1628 & 1573 & 1046 \\
6 & 615 & 1199 & 1090 & 501 & 1880 & 1041 & 1874 & 1632 \\
7 & 1284 & 1836 & 1451 & 1612 & 240 & 1849 & 242 & 1014 \\
8 & 1899 & 1024 & 1954 & 1056 & 1799 & 570 & 698 & 787 \\
9 & 979 & 284 & 299 & 727 & 449 & 1218 & 454 & 338 \\
10 & 1732 & 574 & 1141 & 1377 & 699 & 1322 & 1031 & 1822 \\
\hline
\end{tabular}

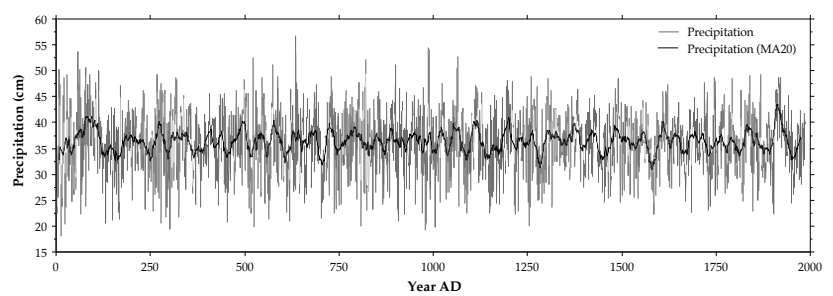

Fig. 4. Fall to Summer Precipitation variability from AD 1 to 1989. Because of chronology depth considerations only the period from AD 200 to 1989 was used in the analysis. Extreme high precipitation interval in the early 1900 s is the greatest 20 -year moving average in the record.

multidecadal scale variability. While the composite chronology extends from AD 1 to 1989 (Fig. 4), the precipitation analysis reported in Table 2 is limited to the period AD 200 to 1989 due to inadequate chronology depth prior to AD 200.

Having established the potential for the reconstruction of annual September to August precipitation, a cross-calibration and verification approach was used to test the general form of the regression equation for the composite chronology (Fritts et al., 1990; Fritts, 1991). The precipitation series from NOAA Arizona Region 2 (NCDC, 1994) near the center of the study region was divided into two 46-year periods: 1896 to 1942 and 1943 to 1989 . A regression equation was fit to the data from the first period and the derived coefficients were then applied to the growth data over the second period to give precipitation estimates that could be compared with the observed climatic data. The process was then repeated with the periods reversed. The results show that over 50 percent of the independent precipitation variance is recovered in the estimated data. For the 1895 to 1942 verification period, the Reduction of Error $(R E)$ statistic was 0.59. For the 1943 to 1989 period, $R E$ was 0.54 . Values above zero indicate that the reconstruction approach is useful for climate prediction (Fritts, 1976; Fritts et al., 1990; Fritts 1991).

Having shown the validity of the general regression model, we recalibrated the reconstruction equation using the entire 94 years of climate and growth data for Arizona Climate Di- vision 2 (NOAA, 1994). The regression equation indicates that $\approx 58$ percent of the variance in indexed ringwidths for the period AD 1895 to AD 1989 is explained by annual precipitation $\left(R=0.760\right.$, Adj. $R^{2}=0.578$, Prob. $\left.<0.0001\right)$ and is expressed by Eq. (1):

Indexed Ringwidth $=-0.109+0.021^{*}$ Annual Precipitation $(\mathrm{cm})(1)$

\section{Results}

\subsection{Dendrogeomorphology}

The ages of pinyons sampled ranged from approximately 80 to 440 years with vertical root exposure estimated vertical erosion rates of $\sim 0.188 \mathrm{~cm} / \mathrm{yr}$ (McAuliffe et al., 2006). Most of the trees were located on planar sideslopes, but several were positioned directly on top of sharp spur ridgecrests and one was located at the bottom of a ravine-like, first order drainage. There is no apparent difference in root exposure in trees from the lower versus upper halves of the slope or in different microtopographic settings (Fig. 5). This indicates that hillslope retreat since the late-1500s has been roughly parallel to the existing surface. Similar erosion rates derived from cosmogenic dating (McFadden et al., 2005) and recent LiDAR mapping (Wawrzyniec et al., 2008) of other local slopes suggest that the erosion rates found and quantified using dendrochronology are characteristic for most slopes in the area.

The majority of the sampled trees show evidence of soil creep with significant bending of younger trees $(<150$ years old) and relict trunk distortion on older trees (Fig. 3). These trees stabilize as they age by producing a laterally spreading root crown that prevents rotational tipping. However since trees of all ages and in all microclimatic settings on slopes show some degree of bending, we conclude that movement of surface materials has occurred on this slope since germination of the oldest trees in the late-1500s.

The $C$ horizon and upper few centimeters of the bedrock, weakly cemented by clays with no carbonate cementation (Tillery et al., 2003), contain prominent, laterally continuous shrink-swell fractures that are subparallel to the surface and apparently form in response to expansion and contraction of clays in wetting and drying cycles (McAuliffe et al., 2006). Pinyon roots are usually no deeper than $\sim 30 \mathrm{~cm}$ and typically occupy these shrink-swell fractures within the $C$ horizon, the interface between $C$ and $R$ horizons, and the upper few centimeters of the $R$ horizon. Following surface erosion, a new and deeper set of shrink-swell fractures are quickly colonized by roots resulting in further mechanical and chemical weathering of bedrock. The establishment of multiple root crowns for pinyon on eroded slopes suggests that the trees that we sampled have survived multiple episodes of weathering and erosion over their lifetimes. 


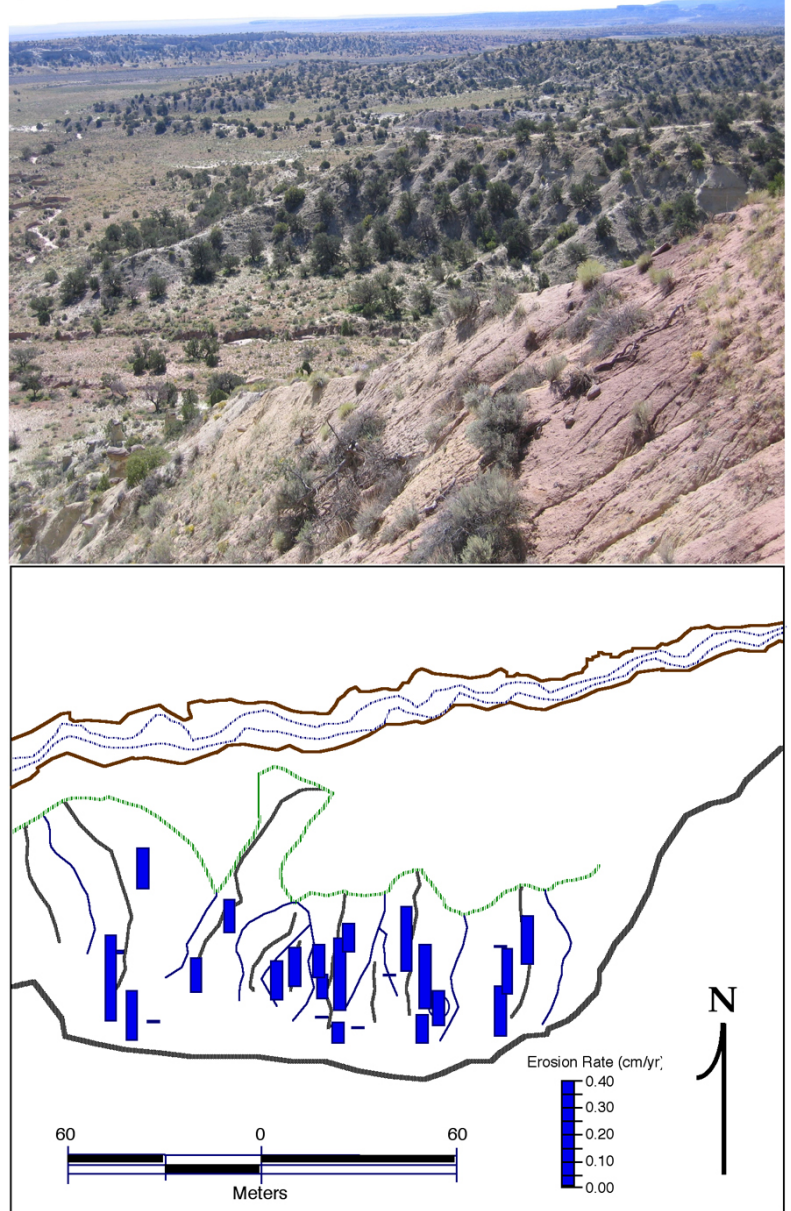

Fig. 5. Upper: Study area pinyon covered hillslope to the south across relatively barren eroded slope. Lower: Location of pinyon pines cored and erosion rates for individual trees. Base of blue bar is position of tree. Dark black line represents the upper drainage divide while light gray lines are local drainage divides on the slope. Dotted green line is the base of the hillslope as it transitions to an alluvial apron/recent abandoned valley floor; the later areas are characterized by tree burial. Light blue lines are slope drainages. Dark brown lines are arroyo edges and dotted blue lines within the arroyo represent the active channel. All positions derived from GPS transects of slope and surrounding area and subsequent post-processing.

\subsection{Dendroclimatology}

The reconstructed annual precipitation series that starts in AD 1 (Fig. 4) (1895-1989 calibration period: adjusted $R^{2}=0.58, p<0.0001$ ) shows that precipitation has varied in a regular manner with alternating wet and dry periods over the last 2000 years. The reconstruction for individual years ranges from a minimum of $19.2 \mathrm{~cm}$ (AD 980) to a maximum of $56.8 \mathrm{~cm}(\mathrm{AD} 636)$. The wettest 20-year interval occurs from AD 1905-1924 (mean $43.4 \mathrm{~cm} / \mathrm{yr}$ ) while the driest occurs from AD 1573-1592 (mean $30.7 \mathrm{~cm} / \mathrm{yr}$ ) (Table 2). Re-

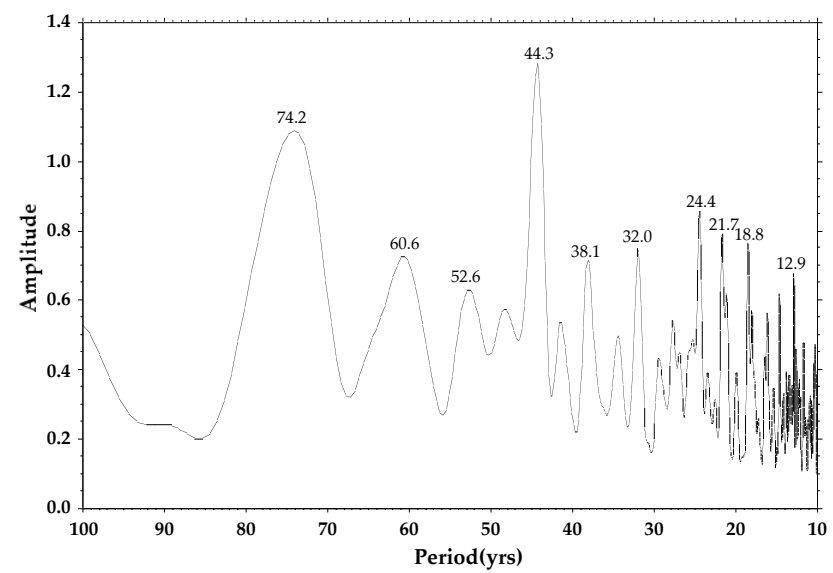

Fig. 6. Blackman-Tukey spectra of the 1989-year chronology. Significant frequencies found at $74.2,44.3$ and 24.4 years ( 0.95 percent confidence interval). Other peaks noted are significant at the 0.80 confidence level.

constructed mean annual precipitation over the 2000-year interval is $36.2 \mathrm{~cm}$ (during the calibration period of from $\mathrm{AD}$ 1895 to 2007 precipitation has averaged $36.6 \mathrm{~cm} / \mathrm{yr}$ ). Of the dry intervals, major droughts in the late $1200 \mathrm{~s}, 1400 \mathrm{~s}$ and 1500 s correspond to previously identified dry periods (Woodhouse and Overpeck, 1998). Multiple sources suggest that the drought of the 1950s was eclipsed several times by droughts over the last 2000 years (Cook et al., 2004a; Meko et al., 1995; D'Arrigo and Jacoby, 1991; Grissino-Mayer, 1996). Our work confirms this and also suggests that some earlier droughts were multidecadal with several (centered on AD 615, 710, 1090, 1280, 1450 and 1580) exceeding drought magnitudes experienced in the 20th century.

\subsection{Spectral analysis}

Analysis of long-term trends indicates that there are periodic variabilities in the Arizona Climate Division 2 precipitation reconstruction. The power spectral density (Fig. 6) shows spectral lines (80 percent confidence) at $\sim 74,61,44$, $38,32,24,22,19$ and 13 years. Of these the 74, 44 and 24-year periodicities are significant at the 95 percent confidence level. Bandpass filters were used to extract the variance in narrow frequency ranges (bandwidth 0.005) centered on 74, 44 and 24-years respectively (Fig. 7a and b, 24-year bandpass filter not shown). The 74 and 44 -year filtered values both show a decrease in variance between AD 800 and 1050 , an interval during which populations in the region expanded and agriculture intensified (Larson and Michaelsen, 1990). The 74-year filtered values show a marked increase in variance after AD 1800 while the 44-year band pass filtered values show variability in a regular and alternating pattern approximately every 440 years. The 74 and 44 -year bandpassed filter values were combined and plotted against the 20 -year moving average of the precipitation reconstruction 

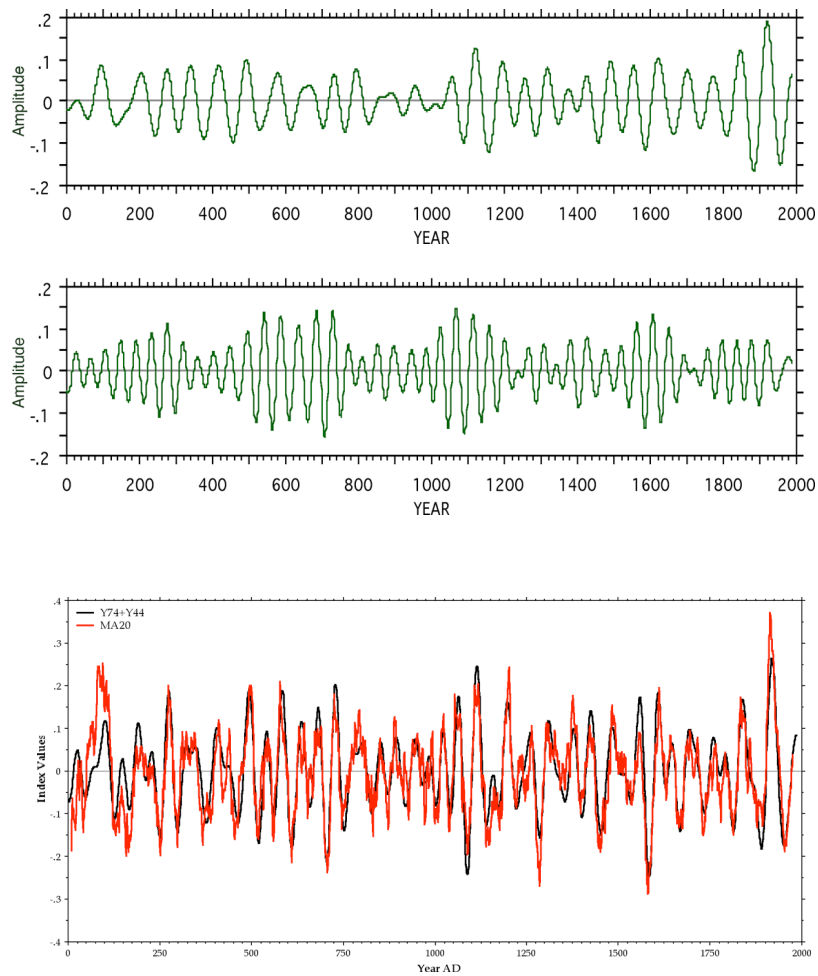

Fig. 7. Bandpass filtered Arizona Climate Division 2 precipitation reconstruction. (a) 74-years, (b) 44.3-years, (c) combined 74 and 44-year bandpassed filtered data (black line) and the 20-year moving average of the precipitation reconstruction (red line). Adjusted $R^{2}$ is 0.702 (p-value $<0.0001$ ).

(Fig. 7c). Approximately 70 percent of the variance in the smoothed record is explained by these two frequencies (adjusted $\left.R^{2}=0.701, p<0.0001\right)$. No other combination of frequencies explained more than 50 percent of the variance in the record.

Previous work has shown that variability in the Palmer Drought Severity Index (PDSI) in the western United States is related to changes in the signs of the Pacific Decadal Oscillation (PDO) and Atlantic Multidecadal Oscillation (AMO) with significant decadal and pentadecadal oscillations on timeframes of 40 to 80 years (Schlesinger and Ramankutty, 1994, Griffies and Bryan, 1997; Delworth and Mann, 2000; Collins and Sinha, 2003; Hidalgo, 2004). McCabe et al. (2004) found that more than half of the spatial and temporal variance in drought frequency over the conterminous United States is attributable to the PDO and AMO, with positive AMO and negative PDO index values associated with drought in the southwestern United States. Our precipitation reconstruction resembles the PDSI reconstruction for northeastern Arizona (Cook, et al., 1999, 2004a, 2004b, - Grid Cell 104) and shares the periodicities found in other records of western North American drought.
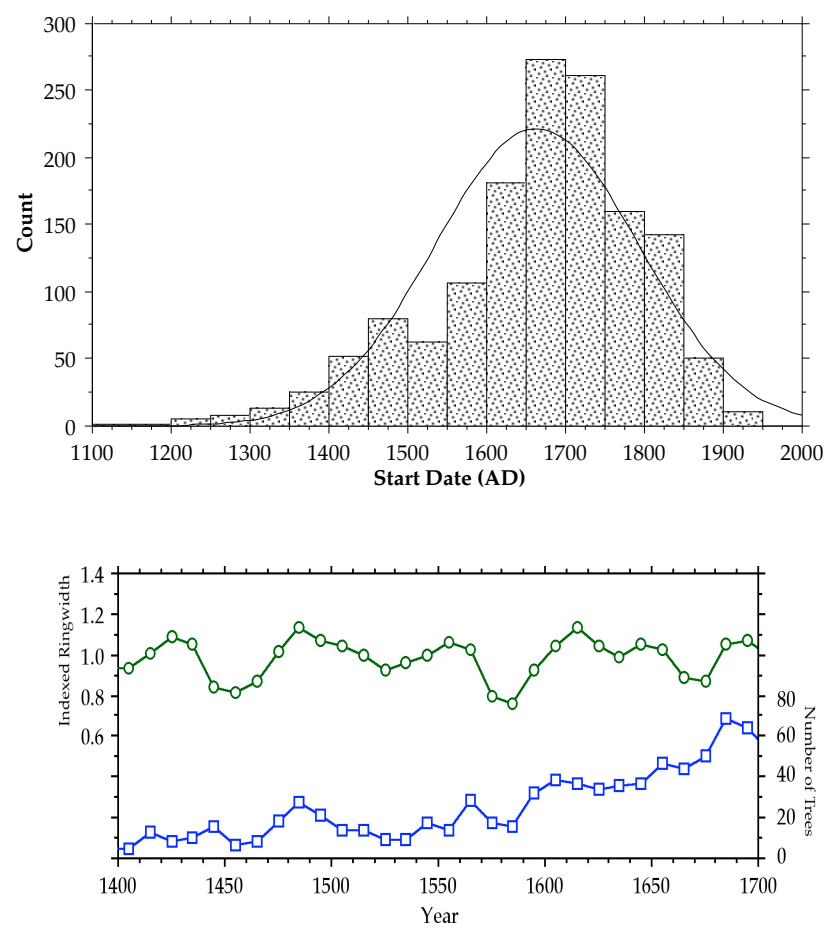

Fig. 8. (a) Germination dates for 1440 pinyon pines included in the site dataset. A significant "missing cohort" is apparent between the early 1500 s to mid-1600s and is followed by an increase in germination in the late-1600s and early 1700s during the Little Ice Age, (b) Indexed ringwidth (green curve) and number of trees germinating per decade (blue curve -not standardized for increasing trend of germination over time). Decreases in ringwidth are correlated with germination declines.

\subsection{Population dynamics}

The sample of 1440 pinyon pines exhibits an age structure with two pronounced anomalies between AD 1500 and 1750 (Fig. 8a). The first, a negative anomaly representing a drop in pinyon establishment, occurs between AD 1500 and 1650 when the number of germinating trees is well below the preand post-period trend, while the second occurs between $\mathrm{AD}$ 1650 and 1750 when the number of trees established is above normal. Taking a 10-20 year height/growth offset into account places the tree ring and germination date chronologies in correspondence with each other during the interval $\mathrm{AD}$ 1400 to 1700 (Fig. 8b). This suggests that low precipitation (low growth) periods are associated with drought induced germination failures and that strong reestablishment occurs during the following wetter periods. The missing pinyon cohort dating to the AD 1500 to 1650 interval strongly suggests de-vegetation of the slopes across the region and at our study site in response to the extreme drought conditions experienced during the 1500s. Megadrought conditions documented in this and previous studies (Stahle, et al., 2000) suggest that this drought was among the most severe in the 
entire record (Table 2).

Juniper on drier, south facing, slopes approximately $1 \mathrm{~km}$ north of our pinyon site are found on bare rock surfaces with exposed root systems. Most of the 22 sampled living and dead trees germinated between the early 1200 s to mid 1700 s. While two of these trees died in 1625 and 1797, the majority of these trees died between 1860 and 1917. This suggests that the juniper population on xeric southern slopes was also continuously impacted by the same climatic conditions that impacted the pinyon community on more mesic northern slopes. Dendrogeomorphic evidence (e.g. extreme root exposure) suggests that rates of erosion on these slopes may have episodically exceeded those documented on the more mesic, north-facing, pinyon covered slopes.

Recent observations of plant mortality in the study area during the most recent drought (McAuliffe et al., 2006) and across the Colorado Plateau (Yuhas and Scuderi, Geographical Research, in press, 2009) indicate a strong reduction in cover and an inability of plants to initiate vegetative growth from any belowground plant parts that may have survived. In our study area, pinyon pine and sagebrush (Artemisia tridentata) have recently died, indicating that extreme, prolonged drought is also capable of eliminating both larger woody shrubs and trees.

\section{Linking dendrogeomorphic evidence of slope move- ment to climate}

Geomorphic and stratigraphic evidence of regionally synchronous shifts between aggradation and incision in channels throughout the American southwest prior to the settlement period (AD 1840 to 1880) suggest that climate variability may be an important driver of erosion and deposition (Huntington, 1914; McFadden and McAuliffe, 1997; Waters and Haynes, 2001; Hereford, 2002). A major impediment to an understanding of the link between climate and landscape change, both in the past and as a predictor for the future, has been the relatively coarse resolution of landscape response measures (rates of weathering, sediment production, erosion and transport) relative to the higher resolution knowledge of the input climatic signal (precipitation and temperature on hourly to annual time scales).

High temporal and spatial resolution dendroclimatic and dendrogeomorphic approaches were used to study relationships between climatic variability and hillslope and valley floor dynamics in a small drainage basin in the Colorado Plateau of northeastern Arizona, USA Dendrogeomorphic and vegetation evidence from slopes and valley bottoms, including root exposure, bending of trunks, change in plant cover and burial and exhumation of valley bottom trees and shrubs, suggest that the currently observed process of root colonization and rapid breakdown of the weakly cemented bedrock by subaerial weathering, related to dry/wet cycle induced changes in vegetation cover, has lead to a discontin- uous, climate-controlled production of sediment from these slopes. We interpret negative increment growth anomalies (geomorphic drought) in hillslope trees as the consequence of rapid aerial exposure of roots by erosion. Two major alluvial fills on the adjacent valley floor are also linked to the abrupt changes in precipitation regimes and associated increases in delivery of runoff and sediments from slopes (McAuliffe et al., 2006).

Our long reconstruction of precipitation variability for Arizona Climate Division 2 shows marked evidence for repeated rapid transitions from extreme drought to mesic conditions (Fig. 4, Table 2), with dendrogeomorphic evidence for a consistent vegetation response to this climatic variability. This combination of a periodically changing climatic background signal possibly linked to changes in the state of the Atlantic and Pacific Oceans (McCabe et al., 2004; Hidalgo, 2004) coupled with processes that alter the vegetative cover on hillslopes appears to be the major driver of erosion on these slopes and deposition in adjacent valley bottoms and channels over the past 2000-years. Dendrogeomorphically documented changes in slope behavior and valley fill (McAuliffe et al., 2006) strongly suggest that the process of sediment production and delivery to adjacent channels occurs in response to these climatic/vegetation variations.

Dendroclimatic reconstructions across the SWNA region indicate that these climatic transitions have occurred on a regular basis for the past 2000 years with periodicities of $\sim 74$-years and 44-years. The most recent documented transition began a few years after AD 1905 and was associated with the largest precipitation shift (dry to wet) in the last 2000 years and a significant loss of weathered material off slopes in the study area. Similar, albeit smaller, transitions, concurrent vegetation change and slope response occurred during the Little Ice Age. Larger shifts associated with major megadrought scale transitions (Stale et al., 2001) appear to operate on timescales of approximately 450 years with earlier occurrences in the 700s, 1100s, and late-1500s.

High-amplitude precipitation shifts over the last 2000years may exert the largest control on landscape processes and may be as, or more, important than other hypothesized causal mechanisms (e.g. ENSO frequency and intensity, flood frequency) in producing sediments that ultimately impact higher order drainages in the region. Current vegetation response to a prolonged drought over the past decade suggests that the processes that we and others have documented (Allen and Breshears, 1998; Breshears et al., 2005; McAullife et al., 2006; Yuhas and Scuderi, in press, 2009) continue to impact the region and that another major transition, incorporating vegetation change, slope erosion, sediment production and subsequent valley floor deposition, may be in its initial phase. 


\section{Conclusions}

The major results of this research can be summarized as follows:

1. Dendrogeomorphic evidence suggests that root colonization and rapid breakdown of weakly cemented bedrock by subaerial weathering, has lead to a discontinuous, climate-controlled production of sediment from slopes in our study area.

2. Negative growth anomalies in hillslope trees are the consequence of rapid aerial exposure of roots by erosion during climatic transitions with dendrogeomorphic evidence for a consistent vegetation response to this climatic variability.

3. The 2000-year precipitation reconstruction for Arizona Climate Division 2 indicates repeated rapid decadalscale transitions from xeric to mesic conditions.

4. These high-amplitude decadal-scale precipitation shifts may exert the largest control on landscape processes and may be the most important causal mechanism in producing sediments that ultimately impact higher order drainages in the region.

Acknowledgements. This study was conducted on lands of the Navajo Nation and we thank the Navajo Nation for the opportunity to conduct this continuing research. Since 1997, many individuals have accompanied and assisted us in the field, including Peter Fawcett, Grant Meyer, David Gutzler, Jennifer Loomis, Laura Crossey, Anne Tillery, and Benjamin Burnette. We would like to thank them for fruitful discussions on a number of topics related to the material presented in this paper. Image processing, GPS and GIS analysis for this study was completed at the Center for Rapid Environmental Assessment and Terrain Analysis funded by NASA Earth Science Enterprise to LAS under grants NAG13-03020 and NNS04AB25G. We would also like to thank two anonymous reviewers whose comments and suggestions improved both the structure and clarity of this manuscript.

Edited by: M. Stoffel

Reviewed by: two anonymous referees

\section{References}

Alestalo, J.: Dendrochronological interpretation of geomorphic processes, Fennia, 105, 1-140, 1971.

Allen, C. D. and Breshears, D. D.: Drought-induced shift of a forest-woodland ecotone: Rapid landscape response to climate variation, P. Natl. Acad. Sci. USA, 95, 14 839-14 842, 1998.

Breshears, D. D., Cobb, N. S., Rich, P. M., Price, K. P., Allen, C. D., Balice, R. G., Romme, W. H., Kastens, J. H., Floyd. M. L., Belnap, J., Anderson, J. J., Myers, O. B., and Meyer, C. W.: Regional vegetation die-off in response to global-change-type drought, P. Natl. Acad. Sci. USA, 102, 15 144-15 148, 2005.

Briffa, K.R., Jones, P.D., Bartholin, T.S., Eckstein, D., Schweingruber, F.H., Karlén, W., Zetterberg, P., and Eronen, M.: Fennoscandian summers from AD 500: temperature changes on short and long timescales, Clim. Dynam., 7, 111-119, 1992.

Bryan, K.: Date of channel trenching (arroyo cutting) in the arid southwest. Science, 62, 338-344, 1925.

Burnett, B. N.: Aspect and Microclimate Influences on Hillslope Geomorphology, Northeastern Arizona, M.S. Thesis, Univ. New Mexico, Albuquerque, USA, 85 pp., 2004.

Burnett, B. N, Meyer, G. A., and McFadden, L. D.: Aspectrelated microclimatic influences on slope forms and processes, northeastern Arizona, J. Geophys. Res., 113, F03002, doi:10.1029/2007JF000789, 2008.

Carrara, P. and Carroll, T. R.: The determination of erosion rates from exposed tree roots in the Piceance Basin, Colorado, Earth Surf. Processes, 4, 307-317, 1979.

Collins, M. and Sinha, B.: Predictability of decadal variations in the thermohaline circulation and climate, Geophys. Res. Lett., 30, 1306, doi:10.1029/2002GL016504, 2003.

Contributors of the International Tree-ring Data Bank: IGBP PAGES/World Data Center for Paleoclimatology, NOAA/NGDC Paleoclimatology Program, Boulder, Colorado, USA, 2007.

Cook, E. R., Briffa, K. R., Meko, D. M., Graybill, D. S., and Funkhouser, G.: The "segment length curse" in long tree-ring chronology development for paleoclimatic studies, Holocene, 5(2), 229-237, 1995.

Cook, E. R., Briffa, K. R., Shiyatov, S., and Mazepa, V.: Tree-ring standardization and growth-trend estimation, in: , Methods of Dendrochronology: applications in the Environmental Sciences, edited by: Cook, E. R. and Kairiukstis, L. A., International Institute for Applied Systems Analysis, Kluwer Academic Publishers, Boston, MA, 104-123, 1990.

Cook, E. R., Meko, D. M., Stahle, D. W., and Cleaveland, M. K.: Drought reconstructions for the continental United States, J. Climate, 12, 1145-1162, 1999.

Cook, E. R., Woodhouse, C. A., Eakin, C. M., Meko, D. M., and Stahle, D. W.: Long-term aridity changes in the Western United States, Science, 306, 1015-1018, 2004a.

Cook, E. R., Meko, D. M., Stahle, D. W., and Cleaveland, M. K.: North American Summer PDSI Reconstructions, IGBP PAGES/World Data Center for Paleoclimatology, Data Contribution Series \# 2004-045, NOAA/NGDC, Paleoclimatology Program, Boulder CO, USA, 2004b.

Cooke, R. U. and Reeves, R. W.: Arroyos and Environmental Change, Clarendon Press, Oxford, UK, 213 pp., 1976. 
D'Arrigo, R. D. and Jacoby, G. C.: A 1000-year record of winter precipitation from northwestern New Mexico, USA: a reconstruction from tree-rings and its relation to El Niño and the Southern Oscillation, Holocene 1(2), 95-101, 1991.

Danzer, S. R.: Rates of slope erosion determined from exposed roots of ponderosa pine at Rose Canyon Lake, Arizona, in: Tree Rings, Environment and Humanity, edited by: Dean, J., Meko, D. M., and Swetnam, T. W., Department of Geosciences, The University of Arizona, Tucson, USA, 671-678, 1996.

Dean, J. S. and Robinson, W. J.: Expanded Tree-Ring Chronologies for the Southwestern United States, Laboratory of Tree-Ring Research Chronology Series 3, U. Arizona, Tucson, USA, 1978.

Delworth, T. L. and Mann, M. E.: Observed and simulated multidecadal variability in the Northern Hemisphere, Clim. Dynam., 16, 661-676, 2000.

Dunne, T., Dietrich, W. E. and Brunengo, J.: Recent and past erosion rates in semi-arid Kenya, Zeitschrift fur Geomorphology N. F., Supplementband 29, 130-140, 1978.

ESRI: ArcGIS (Version 9.3), Environmental Systems Research Institute, Redlands, CA, USA, 2007.

Floyd, M. L., Hanna, D. D., and Romme, W. H.: Historical and recent fire regimes in Pinon-Juniper woodlands on Mesa Verde, Colorado, USA, Forest Ecology and Management, 198, 269289, 2004.

Fritts, H. C.: Tree Rings and Climate, Academic Press, London, UK, 1976

Fritts, H. C., Guiot, J., and Gordon, G. A., in: Methods of Dendrochronology, edited by: Cook, E. R. and Kairiukstis, L. A., Kluwer Academic, Dordrecht, The Netherlands, 178-185, 1990.

Fritts, H. C.: Reconstructing Large-Scale Climatic Patterns from Tree-Ring Data, Univ. of Arizona Press, Tucson, AZ, USA, 1991.

Gartner, H.: Tree roots - Methodological review and new development in dating and quantifying erosive processes, Geomorphology, 86, 243-251, 2007.

Gray, S. T., Betancourt, J. L., Jackson, S. T., and Eddy, R. G.: Role of multidecadal climate variability in a range extension of pinyon pine, Ecology, 87, 1124-1130, 2006.

Griffies, S. M. and Bryan, K.: Predictability of North Atlantic multidecadal climate variability, Science, 275, 181-184, 1997.

Grissino-Mayer, H.: in: Tree Rings, Environment and Humanity,, edited by: Dean, J.S., Meko, D. M., and Swetnam, T. W., Radiocarbon, Tucson, AZ, USA, 191-204, 1996.

Hereford, R.: Valley-fill alluviation during the Little Ice Age (ca. AD 1400-1880), Paria River basin and southern Colorado Plateau, United States, Geologic Society of America, Bulletin, 114, 1550-1563, 2002.

Hidalgo, H. G.: Climate precursors of multidecadal drought variability in the western United States, Water Resour. Res., 40, W12504, doi:10.1029/2004WR003350, 2004.

Hough, W.: Pueblo environment, American Association for the Advancement of Science, Proceedings, 55, 447-454, 1906.

Hughes, M. K. and Funkhouser, G.: Extremes of moisture availability reconstructed from tree rings for recent millennia in the Great Basin of Western North America, in: The Impacts of Climate Variability on Forests, Beniston, M. and Innes, J. L., Springer Verlag, Berlin, Germany, 99-107, 1998.
Huntington, E.: The climate factor, Carnegie Institute Washington, USA, Publication 192, 33-34, 1914.

LaMarche, V. C.: Rates of slope degradation as determined from botanical evidence, White Mountains, California, US Geological Survey Professional Paper 352-I, US Government Printing Office, Washington DC, USA, 341-377, 1968.

Larson, D. O. and Michaelsen, J.: Impacts of climatic variability and population growth on Virgin Branch Anasazi cultural developments, Am. Antiquity, 55(2), 227-249, 1990.

McAuliffe, J. R.: A rapid survey method for the determination of density and cover in desert plant communities, J. Veg. Sci., 1, 653-656, 1991.

McAuliffe, J. R., Scuderi, L. A., and McFadden, L. D.: Tree-ring record of hillslope erosion and valley floor dynamics: Landscape responses to climate variation during the last $400 \mathrm{yr}$ in the Colorado Plateau, northeastern Arizona, Global Planet. Change, 50, 184-201, 2006.

McAuliffe, J. R., Sundt, P. C., Valiente-Banuet, A., Casas, A., and Viveros, J. L.: Pre-Columbian soil erosion, persistent ecological changes, and collapse of a subsistence agricultural economy in the semi-arid Tehuacán Valley, Mexico's "Cradle of Maize", J. Arid Environ., 47, 47-75, 2001.

McCabe, G. J., Palecki, M. A., and Betancourt, J. L.: Pacific and Atlantic Ocean influences on multidecadal drought frequency in the United States, P. Natl. Acad. Sci. USA, 101, 4136-4141, 2004.

McFadden, L. D. and McAuliffe, J. R.: Lithologically influenced geomorphic responses to Holocene climatic changes in the southern Colorado Plateau, Arizona: a soil-geomorphic and ecological perspective, Geomorphology, 19, 303-332, 1997.

McFadden, L. D., Gosse, J., McAuliffe, J. R., Scuderi, L., Meyer, G., and Burnett, B.: Determination of hillslope erosion rates during the late-Holocene based on cosmogenic surface age dating of hoodoos, Northeastern Arizona, Geologic Society of America, Salt Lake City, Paper No. 100-4, 2005.

Meko, D. M., Stockton, C. W., and Boggess, W. R.: The tree-ring record of severe sustained drought, Water Resour. Bull., 31(5), 789-801, 1995.

Meko, D. M., Woodhouse, C. A., Baisan, C. A., Knight, T., Lukas, J. J., Hughes, M. K., and Salzer, M. W.: Medieval drought in the upper Colorado River Basin, Geophys. Res. Lett., 34, L10705, doi:10.1029/2007GL029988, 2007.

NCDC: Time Bias Corrected Divisional Temperature-PrecipitationDrought Index, Documentation for dataset TD-9640, NCDC, NOAA, USA, 12 pp., 1994.

Patton, P. C. and Schumm, S. A.: Ephemeral stream processes: implications for studies of Quaternary valley fills, Quaternary Res., 15, 24-43, 1981.

Rich, J. L.: Recent stream trenching in the semi-arid portion of southwestern New Mexico, a result of removal of vegetation cover, Am. J. Sci., 32, 237-245, 1911.

Schlesinger, M. E. and Ramankutty, N.: An oscillation in the global climate system of period 65-70 years, Nature, 367, 723-726, 1994.

Schumm, S. A.: The Fluvial System, John Wiley and Sons, New York, USA, 1977.

Schumm, S. A.: To Interpret the Earth, Ten Ways to be Wrong, Cambridge Univ. Press, Cambridge, UK, 1991. 
Seager, R., Ting, M., Held, I., Kushnir, Y., Lu, J., Vecchi, G., Huang, H., Harnik, N., Leetmaa, A., Lau, N., Li, C., Velez, J., and Naik, N.: Model Projections of an Imminent Transition to a more arid climate in Southwestern North America, Science, 316, 1181-1184, 2007.

Stahle, D. W., Cook, E. R., Cleaveland, M. K., Therrell, M. D., Meko, D. M., Grissino-Mayer, H. D., Watson, E., and Luckman, B. H.: Tree-ring data document 16 th century megadrought over North America, EOS, Transactions of the American Geophysical Union, 81(12), 121, 2000.

Swift, T. T.: Date of channel trenching in the southwest, Science 63, 70-71, 1926.

Tillery, A., Fawcett, P., McFadden, L., Scuderi, L., McAuliffe, J.: Late Holocene Behavior of Small Drainage Basins on the Colorado Plateau: Influences of Lithology, Basin Form, and Climate Change, New Mexico Geol. Soc. Guidebook, 54th Field Conf., Geology of the Zuni Plateau, 197-207, 2003.

Vandekerckhove, L., Muys, B., Poesen, J., De Weerdt, B. and Coppe, N.: A method for dendrochronological assessment of medium-term gully erosion rates, Catena, 45, 123-161, 2001.

Waters, M. R. and Haynes, C. V.: Late Quaternary arroyo formation and climate change in the American Southwest, Geology, 29, 399-402, 2001.
Wawrzyniec, T. F., McFadden, L. D., Ellwein, A., Meyer, G., Fawcett, P., and Scuderi, L. A.: Chronotopographic analysis directly from point cloud data: A method for detecting small, seasonal hillslope change, Black Mesa Escarpment, NE Arizona, Geosphere, GEOS-00110R, 2008.

Wigley, T. M. L., Jones, P. D., and Briffa, K. R.: Cross-dating methods in dendrochronology, J. Archaeol. Sci., 14, 51-64, 1987.

Woodhouse, C. A. and Overpeck, J. T.: 2000 years of drought variability in the central United States, Bulletin of the American Meteorological Society, 79, 2693-2714, 1998.

Yang, D., Kanae, S., Oki, T., Koike T., and Musiake, K.: Global potential soil erosion with reference to land use and climate changes, Hydrol. Process., 17, 2912-2928.

Yuhas, A. N. and Scuderi, L. A.: MODIS-derived NDVI characterisation of drought-induced evergreen dieoff in Western North America, Geogr. Res., in press, 2009.

Zhang, X., Zwiers, F. W., Hegerl, G. C., Lambert, F. H., Gillett, N. P., Solomon, S., Stott, P., and Nozawa, T.: Detection of human influence on twentieth-century precipitation trends, Nature, 448 , 461-465, 2007. 